Available online at https:/jurnal.stmikroyal.ac.id/index.php/jurdimas

\title{
PENDAMPINGAN UMKM PENJUAL JAMU DALAM MENINGKATKAN PENJUALAN MELALUI KEMASAN, MEREK, DAN LABEL
}

\author{
Emilda $^{1}$, Try Wulandari ${ }^{1}$, Shafiera Lazuarni ${ }^{1}$ \\ ${ }^{1}$ Program Studi Manajemen, Universitas Indo Global Mandiri Palembang \\ email:emilda@uigm.ac.id
}

\begin{abstract}
Government policies in an effort to reduce the spread of the covid-19 virus, of course, this has an impact on MSMEs, including herbs drink sellers who sell conventionally. The herbs drink sellers in the gang sei saling still offer directly to customers by walking or getting around by bicycle. This activity aims to increase sales of herbs drink during the pandemic through packaging, brands, and labels. The method utilized in this activity is community service activities through mentoring to achieve the objectives of the activity which consists of the stages of preparation, implementation, and evaluation of mentoring activities. The implementation time of mentoring was carried out for 3 days. The implementation of this activity consists of providing an understanding of the importance of packaging, merk, and labeling in increasing sales, determining the right packaging bottles, then making brands and labeling for the sale of packaged herbs drink. In this activity, participants are not only given an understanding of the importance of packaging, brands, and labeling, but also this activity is selling herbs directly and online, having packaging, brands, and labels, increasing sales and customers.
\end{abstract}

Keywords: mentoring; increased sales of herbs drink; herbs drink seller

\begin{abstract}
Abstrak: Kebijakan pemerintah dalam upaya menekan penyebaran virus covid-19, tentunya hal ini berdampak pada pelaku UMKM termasuk penjual jamu tradisional yang masih menggunakan metode konvensional. Penjual jamu di gang sei saling masih menawarkan secara langsung kepada pelanggan dengan cara berjalan kaki atau berkeliling menggunakan sepeda. Kegiatan ini bertujuan untuk meningkatkan penjualan jamu pada masa pandemi melalui kemasan, merek, dan label. Dalam kegiatan pengabdian masyarakat ini, metode yang digunakan adalah melalui pendampingan, untuk mencapai tujuan kegiatan yang terdiri dari tahap persiapan, pelaksanaan, dan evaluasi kegiatan pendampingan. Waktu pelaksanaan pendampingan dilaksanakan selama 3 hari. Kegiatan pelaksanaan kegiatan ini terdiri dari memberikan pemahaman mengenai pentingnya kemasan, merek, dan label dalam meningkatkan penjualan, menentukan botol kemasan yang tepat, selanjutnya adalah membuat merk dan label untuk penjualan jamu kemasan. Dalam kegiatan PkM ini, peserta tidak hanya diberikan pemahaman mengenai pentingnya kemasan, merek, dan label, tetapi juga kegiatan ini penjualan jamu secara langsung dan online, memiliki kemasan, merek, dan label, peningkatan penjualan dan pelanggan.
\end{abstract}

Kata kunci: pendampingan; peningkatan penjualan jamu; penjual jamu 
Jurdimas (Jurnal Pengabdian Kepada Masyarakat) Royal

Vol. 5 No. 1, Januari 2022, hlm. 53 - 60

ISSN 2614-7912 (Print)

DOI: https://doi.org/10.33330/jurdimas.v5i1.1249

ISSN 2622-3813 (Online)

Available online at https:/jurnal.stmikroyal.ac.id/index.php/jurdimas

\section{PENDAHULUAN}

Kemunculan virus covid-19 pada akhir Desember 2019 Wuhan, Cina telah menggemparkan dunia. Terlebih lagi, virus covid-19 menyebar pada berbagai negara dalam waktu yang singkat, hal ini menjadi perhatian yang serius bahwa virus ini berbahaya. Di Indonesia, virus covid-19 diketahui telah menyebar di Indonesia setelah pemerintah indonesia mengumumkan ada kasus covid di Indonesia pada tanggal 2 Maret 2020.

Gejala Covid menurut WHO adalah demam, batuk kering, lelah. Gejala lainnya yang mungkin dialami adalah nyeri sendi, sakit kepala, hidung tersumbat, hingga kehilangan indera rasa atau penciuman. Dampak virus covid-19 bisa menyebabkan gangguan kesehatan hingga kematian. Dampak yang serius ini dari covid-19 membuat seseorang berupaya untuk meningkatkan pencegahan terkena covid-19 baik itu mematuhi protokol kesehatan maupun mengkonsumsi asupan yang meningkatkan daya tahan tubuh, salah satunya minum ramuan tradisional atau jamu.

Pandemi covid-19 selain memberikan banyak permasalahan dalam berbagai aspek, meningkatnya kasus positif dan jumlah orang yang meninggal karena virus Covid-19, hal ini membuat masyarakat merasa pentingnya menjaga kesehatan seperti mengkonsumsi makanan atau minuman herbal yang baik untuk kesehatan tubuh sehingga permintaan jamu tradisional meningkat selama masa pandemi covid-19.

Permintaan yang tinggi akan jamu tidak diikuti oleh meningkatnya penjualan karena metode penjualan jamu masih secara konvensional yang menawarkan jamu secara langsung kepada masyarakat sekitar, sedangkan kebijakan pemerintah dalam mengurangi penyebaran virus covid menerapkan berbagai peraturan seperti beraktivitas dari rumah, social distancing, dan lainlain.

Dengan demikian, banyak konsumen yang kemudian menjaga jarak dan mengalihkan pembelian secara digital. Dampaknya banyak UMKM yang harus menutup usahanya karena menurunya pembelian dan masih tergantung pada penjualan secara offline (Arianto, 2020)

Pandemi covid-19 selain memberikan dampak buruk pada berbagai aspek, namun bagi penjual jamu, pandemi ini menyebabkan peningkatan permintaan akan jamu tradisional. Sebagian besar penjualan jamu masih menggunakan cara tradisional seperti menawarkan jamu berkeliling komplek baik dengan cara berjalan maupun menggunakan sepeda motor. Metode penjualan jamu secara umum menawarkan jamu dan menyajikan jamu dengan menggunakan cangkir yang selalu dibawah oleh penjual jamu. Tentunya, cara penjualan jamu yang seperti ini agak sulit menjangkau konsumen yang lebih banyak. Dengan adanya kelemahan dari metode penjualan jamu tradisional secara konvensional, sehingga diperlukan juga penjualan jamu dalam kemasan sehingga bisa menjangkau konsumen lebih banyak lagi dengan memanfaatkan e-commerce dan social commerce.

Kurangnya pemanfaatan socialcommerce ini bisa disebabkan oleh beberapa faktor, diantaranya kurangnya pengetahuan dan pemahaman mengenai pentingnya e-commerce atau socialcommerce dalam meningkatkan penjualan. Penjualan secara elektronik bisa menggunakan social commerce seperti penjualan dengan memanfaatkan media sosial seperti instagram dan facebook 
Available online at https:/jurnal.stmikroyal.ac.id/index.php/jurdimas

maupun melalui e-commerce seperti gofood atau grabfood. Dalam melakukan penjualan secara online akan membutuhkan kemasan, merek, dan label. Merek dan label sebagai identitas maupun sebagai media promosi. Label kemasan merupakan hal yang penting karena menjadi identitas dari suatu produk (Nugrahani, 2015). Label kemasan paling tidak memiliki informasi nama produk, deskripsi singkat serta nomor telepon yang bisa dihubungi untuk pemesanan.

Penjual jamu tradisional adalah adalah Ibu Rumah Tangga yang memiliki suami dengan penghasilan tidak tetap. Berikut gambar untuk memberikan gambaran mengenai kondisi penjual jamu yang berlokasi di Gang Sei Saling, Kelurahan Siring Agung, Kecamatan Ilir Barat 1, Palembang.

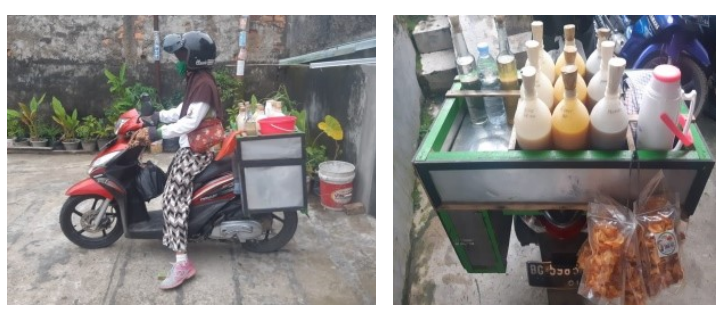

Gambar 1. Penjual Jamu di Gang Sei Saling.

Dari uraian permasalah tersebut Tim Pengabdian bermaksud untuk melakukan penyuluhan dan pendampingan pada pelaku UMKM penjual jamu tradisional yang menawarkan masih menggunakan metode konvensional ke metode secara online (ecommerce) yang membutuhkan kemasan, merek, dan label jamu dengan berkeliling jalan kaki, penjual jamu di gang sei saling untuk menjangkau pelanggan yang lebih luas menggunakan sepeda motor.

\section{METODE}

Kegiatan pengabdian masyarakat pada usaha jamu tradisional yang berlokasi di gang sei saling, kecamatan ilir barat, Palembang. Metode pelaksanaan dalam kegiatan ini melalui pendampingan. Pendampingan adalah suatu kegiatan yang dilakukan seseorang yang bersifat konsultatif, interaktif, komunikatif, motivatif, dan negosiatif (Kamil, 2012). Kegiatan terdiri dari tiga tahap, yaitu:

\section{Tahap Persiapan}

Kegiatan PkM ini diawali dengan melakukan observasi ke lokasi mitra untuk melihat situasi. Setelah melihat situasi dan kondisi dari mitra, tim PkM melakukan wawancara untuk mengetahui permasalahan yang dihadapi mitra.

\section{Tahap Pelaksanaan}

Setelah mengidentifikasi permasalahan mitra, tahap selanjutnya adalah pelaksanaan kegiatan PkM dalam upaya memberikan solusi dari permasalahan yang dihadapi mitra. Tahapan pelaksanaan terdiri dari: (1) memberikan pemahaman mengenai pentingnya kemasan, merek dan label dalam meningkatkan penjualan, (2) menentukan kemasan botol yang akan digunakan, (3) mendesain merek dan label, (4) mencetak merek dan label

\section{Tahap Evaluasi dan Pelaporan}

Setelah tahap pelaksanaan, melakukan evaluasi untuk mengetahui apakah ada perbedaan tingkat jumlah penjualan sebelum dan setelah adanya penjualan jamu dalam kemasan botol.

\section{Jadwal Kegiatan Pendampingan}

Kegiatan pengabdian kepada masyarakat ini dilaksanakan selama 3 hari yang diawali dengan memberikan pemahaman, menentukan, hingga 
Available online at https:/jurnal.stmikroyal.ac.id/index.php/jurdimas

membeli kemasan dan mencetak merek dan label. Berikut jadwal kegiatan pendampingan kepada mitra.

Tabel 1. Jadwal Pendampingan

\begin{tabular}{|c|c|}
\hline Hari & Kegiatan \\
\hline $\begin{array}{l}\text { Hari } \\
\text { Pertama }\end{array}$ & $\begin{array}{l}\text { Memberikan pemahaman } \\
\text { pentingnya kemasan, merek, } \\
\text { dan label }\end{array}$ \\
\hline $\begin{array}{l}\text { Hari } \\
\text { Kedua }\end{array}$ & $\begin{array}{lr}\text { Pendampingan } & \text { dalam } \\
\text { menentukan } & \text { kemasan, } \\
\text { merek, dan label } & \end{array}$ \\
\hline Hari & Pendampingan \\
\hline Ketiga & $\begin{array}{l}\text { kemasan, mendesign merek } \\
\text { dan label, dan mencetak } \\
\text { merek dan label }\end{array}$ \\
\hline
\end{tabular}

\section{PEMBAHASAN}

Dalam tahap pelaksanaan dibagi menjadi 3 tahap yaitu pertama, tim PkM memberikan pemahaman mengenai pentingnya kemasan, merek dan label dalam meningkatkan penjualan. Kedua, menentukan botol kemasan yang tepat untuk penjualan jamu tradisional. Ketiga, tahap selanjutnya adalah membuat merek dan label untuk penjualan jamu tradisional.

Dari observasi dan wawancara yang dilakukan, kita dapat mengidentifikasi permasalahan yang dihadapi mitra. Pada pandemi saat ini, penjual jamu tradisional perlu melakukan penjualan secara online. Dalam melakukan penjualan secara online dibutuhkan kemasan, merek, dan label. Mitra perlu diberikan pemahaman mengenai pentingnya kemasan, merek, dan label dalam meningkatkan penjualan. Kemasan, merek, dan label merupakan bagian dari atribut produk.
Kemasan (Packaging) adalah proses yang berkaitan dengan wadah atau pembungkus untuk suatu produk (Rachmawati, 2011). Keputusan dalam menentukan bentuk dan size kemasan botol untuk jamu tradisional ini adalah segmen pasar dan harga agar bisa didistribusikan lebih luas. Kemasan botol yang dipilih untuk jamu tradisional adalah kualitas dan size botol tidak terlalu kecil dan besar agar harga yang dikenakan kepada pelanggan masih terjangkau. Dalam penentuan kemasan botol yang akan digunakan, tim $\mathrm{PkM}$ membantu memberikan saran baik dalam hal bentuk, size, dan kualitas dari kemasan botol yang akan dibeli. Berikut gambar kemasan botol yang digunakan untuk jamu tradisional.

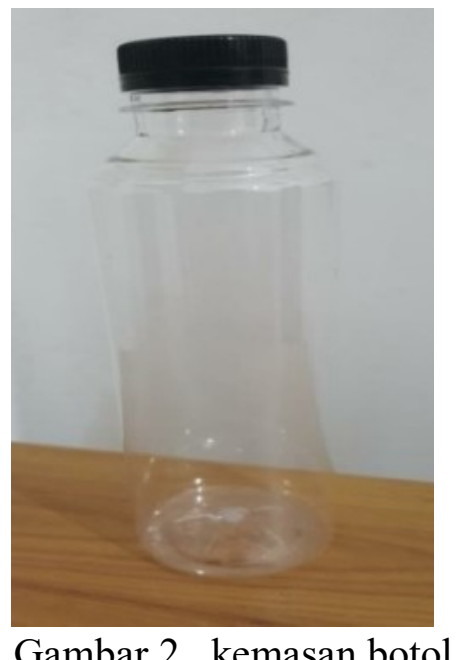

Kemasan botol pada gambar 2 memiliki ketebalan yang sedang sehingga ringan dibawa, namun tidak terlalu mudah remuk sehingga tetap bisa menjaga kualitas dari jamu tradisional. Dalam hal pemilihan size didasari oleh bagi konsumen yang ingin membeli jamu untuk sekali minum tetapi tidak perlu menunggu atau mendatangi tukang jamu tradisional. Oleh karena itu, kapasitas dari kemasan botol ini seukuran dengan 
jamu dalam ukuran 1 gelas sedang. Selain itu, yang mendasari pemilihan size juga adalah harga, semakin besar kemasan botol yang digunakan maka harga botol juga akan lebih mahal sehingga mempengaruhi harga yang akan dikenakan ke konsumen mengingat segmen dari jamu ini adalah menengah kebawah sehingga jamu dalam kemasan diharapkan tidak terlalu jauh beda dari harga jamu per gelas yang biasa dijual sehingga tetap terjangkau oleh pelanggan.

Merek adalah nama, simbol atau lambang yang memberikan identitas produk. Labelling adalah bagian yang menginformasikan mengenai produk dan penjual. Label hendaknya memperjelas informasi kepada konsumen dan mempunyai efek promosi (Rachmawati, 2011). Dalam membuat merek dan label, tim PkM mendatangi jasa percetakan untuk membuat design sekaligus mencetak merek dan label untuk penjualan jamu. Berikut gambar saat tim $\mathrm{PkM}$ mendatangi percetakan untuk mendesign dan mencetak merek dan label.

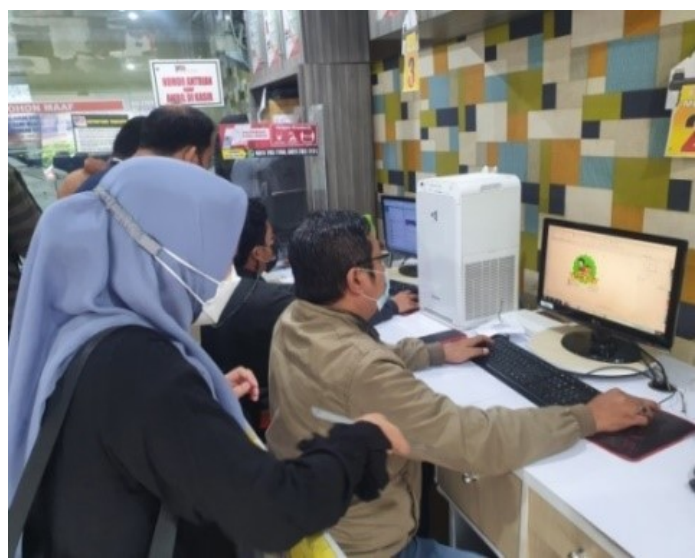

Gambar 3. Membuat Design Merk dan Label

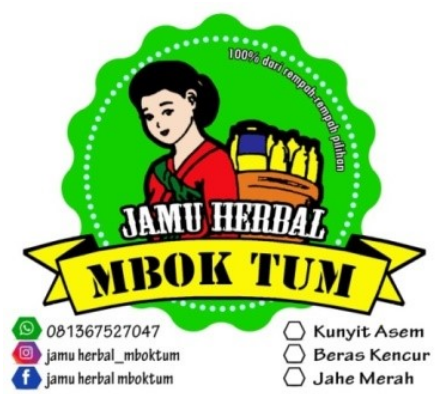

Gambar 4. Design Merk Jamu Tradisional

Merek dari produk jamu tradisional adalah "jamu mbok tum", pemberian Merek dari jamu ini dilatarbelakangi oleh nama pemilik dari jamu tradisional yang bernama tuminah dan memiliki umur diatas 50 tahun. Mengenai label dari merek "jamu mbok tum" memuat tentang informasi mengenai jenis varian, kontak yang dihubungi dan sosial media dari "jamu mbok tum". Berikut gambar kemasan, merek, dan label jamu tradisional untuk mitra.

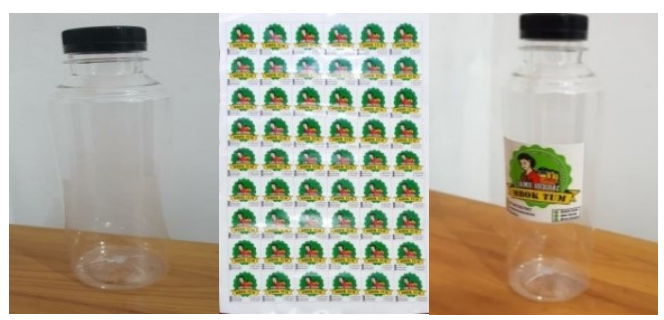

Gambar 5. Kemasan Botol dengan Merek dan Label.

Gambar 5 memberikan gambaran mengenai tahapan dalam melakukan penjualan jamu dalam kemasan botol dimulai dari menentukan kemasan, mendesign merek dan label, mencetak merek dan label dan menempelkan merek dan label pada kemasan botol, kemudian jamu tradisional siap dikemas dalam bentuk untuk memudahkan menjangkau konsumen dalam mempertahankan dan bahkan meningkat 
Available online at https:/jurnal.stmikroyal.ac.id/index.php/jurdimas

penjualan selama masa pandemi covid19.

Setelah kemasan, merek, dan label jamu tradisional dari mitra sudah tersedia, maka penjuaalan secara online siap dilakukan. Penjualan online dari "jamu mbok tum" menggunakan social media seperti whatsapp, facebook, dan instagram. Berikut gambar jamu tradisional setelah dikemas dalam botol untuk dipromosikan secara

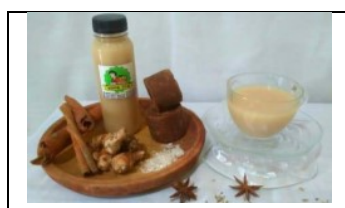

Beras Kencur

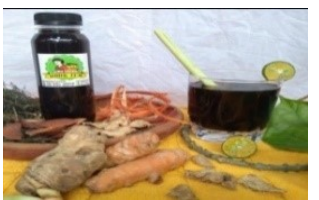

Temulawak

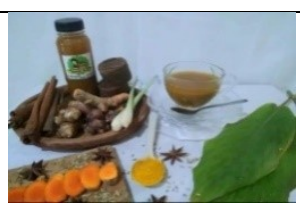

Kunyit Asem

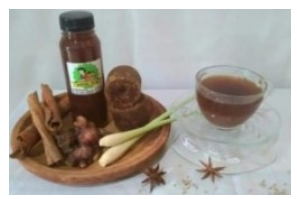

Jahe Merah
Gambar 6. Jamu Kemasan Botol

Dengan adanya kemasan dalam botol, penjualan tidak hanya dilakukan dengan berkeliling menawarkan jamu secara konvensional tetapi juga melakukan penjualan jamu dalam kemasan botol secara online. Merek dan label dalam kemasan selain sebagai identitas dari produk tetapi juga promosi karena dalam label terdapat info kontak dan social media yang bisa dilihat oleh pelanggan. Dengan penjualan dilakukan secara online menjadi solusi dari penurunan penjualan yang disebabkan oleh dampak pandemi sehingga disaat pandemi masih mampu menambah penjualan dari penjualan online untuk menutupi penurunan penjualan secara konvensional.

Dengan adanya penjualan dalam kemasan botol, mampu meningkatkan penjualan dan jumlah pelanggan.
Evaluasi tingkat penjualan dilakukan dengan melihat tingkat penjualan harian dari sebulan setelah dilakukan dengan adanya penjualan dalam kemasan botol juga. Berikut rata-rata tingkat penjualan harian selama sebulan dari sebelum dan setelah adanya penjualan dalam kemasan botol.

Tabel 2. Rata - Rata Penjualan Harian

\begin{tabular}{lcl}
\hline & Sebelum & setelah \\
\hline $\begin{array}{l}\text { Penjualan } \\
\text { (gelas) }\end{array}$ & 180.000 & 160.000 \\
\hline $\begin{array}{l}\text { Penjualan } \\
\text { (Botol) }\end{array}$ & - & 150.000 \\
\hline Total Penjualan & 180.000 & 310.000 \\
\hline
\end{tabular}

Berdasarkan tabel 2, penjualan jamu secara tradisional mengalami penurunan dari bulan sebelumnya, namun penurunan penjualan ini ditutupi dari penjualan dalam kemasan botol sehingga tingkat penjualan mengalami peningkatan secara total.

\section{Evaluasi Kegiatan}

Tahap evaluasi merupakan proses yang berfungsi untuk mengetahui dan mengukur hasil dari pembelajaran yang telah dilaksanakan (Wahyuni \& Sutarto, 2018). Setelah melakukan kegiatan pendampingan, tim $\mathrm{PkM}$ melakukan evaluasi untuk mengetahui bagaimana permintaan jamu dalam kemasan botol, tingkat penjualan jamu dalam kemasan botol, dan apakah dengan adanya penjualan jamu dalam kemasan botol dapat menutupi penurunan penjualan jamu dengan cara konvensional. Dalam melakukan evaluasi, tim PkM mendatangi mitra untuk mengetahui bagaimana dampak packaging, merk, dan labelling dari penjualan dalam kemasan pada tingkat penjualan secara keseluruhan. Berikut hasil evaluasi kegiatan pendampingan 
Available online at https:/jurnal.stmikroyal.ac.id/index.php/jurdimas

Tabel 3. Hasil Evaluasi Kegiatan Pendampingan

\begin{tabular}{|c|c|}
\hline $\begin{array}{l}\text { Kriteria } \\
\text { keberhasilan }\end{array}$ & Hasil Evaluasi \\
\hline $\begin{array}{l}\text { Penjualan } \\
\text { jamu secara } \\
\text { langsung dan } \\
\text { online }\end{array}$ & $\begin{array}{l}\text { Sebelum adanya pen- } \\
\text { dampingan, penjualan } \\
\text { hanya dilakukan se- } \\
\text { cara langsung kepada } \\
\text { pelanggan dengan ber- } \\
\text { keliling. Namun, se- } \\
\text { telah adanya pen- } \\
\text { dampingan, penjualan } \\
\text { juga dilakukan secara } \\
\text { online. }\end{array}$ \\
\hline $\begin{array}{l}\text { Memiliki } \\
\text { kemasan, } \\
\text { merek, dan } \\
\text { label }\end{array}$ & $\begin{array}{l}\text { Dari kegiatan pen- } \\
\text { dampingan ini, penjual } \\
\text { jamu menawarkan } \\
\text { jamu dalam kemasan } \\
\text { juga yang sudah mem- } \\
\text { iliki merek dan label. }\end{array}$ \\
\hline $\begin{array}{l}\text { Peningkatan } \\
\text { Penjualan }\end{array}$ & $\begin{array}{lr}\text { Tingkat } & \text { penjualan } \\
\text { meningkat } & \text { secara } \\
\text { keseluruhan } & \\
\end{array}$ \\
\hline $\begin{array}{l}\text { Peningkatan } \\
\text { Jumlah } \\
\text { Pelanggan }\end{array}$ & $\begin{array}{l}\text { Pelanggan dari jamu } \\
\text { dalam kemasan tidak } \\
\text { hanya dari pelanggan } \\
\text { lama, namun juga dari } \\
\text { pelanggan baru. } \\
\text { Dengan adanya pen- } \\
\text { jualan dalam kemasan, } \\
\text { memungkinkan me- } \\
\text { masarkansecara online } \\
\text { via social media seper- } \\
\text { ti facebook, instagram, } \\
\text { dan whatsapp sehing- } \\
\text { ga dapat menjangkau } \\
\text { pelanggan yang lebih } \\
\text { luas. }\end{array}$ \\
\hline
\end{tabular}

\section{SIMPULAN}

Dari pelaksanaan kegiatan pendampingan penjual jamu yang ada di gang Sei Saling, kecamatan Ilir Barat I, kota Palembang dalam pemilihan kemasan, membuat merk dan label menunjukkan bahwa adanya peningkatan omzet penjualan dikarenakan dengan adanya kemasan, merk, dan label sehingga penjualan tidak hanya dilakukan secara konvensional tetapi juga secara online.

UMKM jamu tradisional di Indonesia masih terkendala beberapa hal terutama dalam pemasaran produk. Kendala tersebut mulai dari packaging, branding hingga teknik pemasaran. Pada masa pandemi Covid-19, penjual jamu tradisional harus dapat bertransformasi dalam dunia digital terutama dalam pemasaran digital. Pengetahuan mengenai pemasaran digital perlu didapat oleh para pelaku UMKM melalui pendampingan dan berbagai pelatihan.

\section{DAFTAR PUSTAKA}

Arianto, B. (2020). Pengembangan UMKM Digital di Masa Pandemi Covid-19. ATRABIS: Jurnal Administrasi Bisnis (e-Journal), 6(2),233-247.

https://www.jurnal.plb.ac.id/inde x.php/atrabis/article/view/512

Giyanti, I., Suparti, E., Sunardi, S., \& Sugiarti, S. (2021). Perbaikan Proses Produksi dan Peningkatan Pemasaran pada UKM Putri Timus Di Karanganyar. Jurdimas (Jurnal Pengabdian Kepada Masyarakat) Royal, 4(2), 127134.

Kamil, M. (2012). Model Pendidikan dan Pelatihan (Konsep dan Aplikasi) (Edisi 10). Bandung: Alfabeta.

Nugrahani, R. (2015). Peran desain grafis pada label dan kemasan produk makanan umkm. Jurnal Imajinasi, $\quad I X(2), \quad$ 127-136. 
Jurdimas (Jurnal Pengabdian Kepada Masyarakat) Royal

Vol. 5 No. 1, Januari 2022, hlm. 53 - 60

Available online at https:/jurnal.stmikroyal.ac.id/index.php/jurdimas

https://journal.unnes.ac.id/nju/ind ex.php/imajinasi/article/view/884 6

Rachmawati, R. (2011). Peranan Bauran Pemasaran (Marketing Mix) terhadap Peningkatan Penjualan. Jurnal Kompetensi Teknik, 2(2), 143-150.

Sari, R., Sayadi, M. H., \& Hildayanti, S. K. (2020). Pelatihan Dalam Menghadapi Tantangan Usaha Kecil Di Era Digital Pada Pelaku Usaha Kecil Di Kenten Palembang. Jurdimas (Jurnal Pengabdian Kepada Masyarakat) Royal, 3(2), 87-92.
Wahyuni, S., \& Sutarto, J. (2018). Pembelajaran Kursus Menjahit di Lembaga Kursus dan Pelatihan Gassebo Kabupaten Kendal. Jurnal Pendidikan Dan Pemberdayaan Masyarakat, Vol 5.

Wiguna, I. K. A., \& Ariana, K. A. (2021). Rancangan Model Digitalisasi Pasar Tradisional Pasar Rare Angon Di Desa Gunaksa. Jurdimas (Jurnal Pengabdian Kepada Masyarakat) Royal, 4(3), 257-262. 